Digital Press Social Sciences and Humanities

Pendalungan Culture's Worldview and Its Role in Handling Covid 19 in Kabupaten Jember

Fitri Alfariz and Rr. Yudiswara Ayu Permatasari

Proceeding of 9th International Conference on Nusantara Philosophy (ICNP) Arndt Graf, Fitri Alfariz, M Rodinal Khair Khasri, Rachmad Hidayat, Rokhmat Sairah, Zaid bin Ahmad (eds) 


\title{
Pendalungan Culture's Worldview and Its Role in Handling Covid 19 in Kabupaten Jember
}

\author{
Fitri Alfariz*, Rr. Yudiswara Ayu Permatasari \\ Faculty of Philosophy, Universitas Gadjah Mada, Yogyakarta \\ *e-mail: alfariz@ugm.ac.id
}

\begin{abstract}
The COVID-19 pandemic is a problem for almost all countries in the world. Each country has its ways and obstacles in dealing with COVID-19. Indonesia is no exception, which has classified the COVID-19 pandemic as a non-natural disaster and each region has the authority to deal with each region effectively. Jember district, as a world carnival city, tries to deal with handling from upstream to downstream or from the smallest level so that it is considered more effective. This study aims to provide input for Kabupaten Jember government to overcome the Pandemic with a cultural approach that is in line with handling efforts from upstream. The world view of culture in Kabupaten Jember is considered capable of being applied by various levels of society as well as health workers and the Kabupaten Jember government. The research method used is qualitative with library data. The methodical elements used are analysis by using data reduction steps, data classification, data display, and interpretation and interpretation of data to obtain conclusions. The results were obtained by applying several categories of worldviews of the Jember Pendalungan culture. This worldview can be applied to health efforts ranging from health promotion, prevention, curative, and rehabilitation. The worldview of the Pendalungan culture is an approach for health workers and the government to get closer to the community to provide education and support for recovery from the COVID19. The world view can be considered capable of handling the COVID-19 pandemic in a cultural approach in Kabupaten Jember. It can also be implemented in other areas according to local wisdom.
\end{abstract}

\section{Keywords}

Pendalungan, worldview, Jember, Covid-19, local wisdom

\section{Introduction}

The COVID-19 pandemic has become a global problem that is still trying to overcome today's Covid virus characteristics that require handling that focuses on personal space for socializing and improving health. Covid-19 is not only a problem that must be controlled by the government but also requires individual selfcontrol to suppress the spread of the virus that has infected many people in the world.

Indonesia has made the covid-19 pandemic a non-natural disaster that is the responsibility of the government to the minor level. One of the regions struggling to deal with covid-19 is Kabupaten Jember, a district located in the eastern part of East Java Province. The district, which is often known as the world's carnival city, has made efforts to handle COVID-19 by suppressing community movements to the village level (Diskominfo.jemberkab.go.id, 2021) and and aims in the future to reach the most minor level at the RT (rukun tetangga) or neighborhood level (Saubani, 2021).

The Regent of Jember declared the program as an upstream to the downstream program which has implications for monitoring and handling people infected with COVID-19 starting from the village level (Diskominfo.jemberkab.go.id, 2021). Of course, with this program, the people of Jember are expected to be able to break the chain of the spread of the COVID-19 virus and handle the infected people more effectively.

Concerning the upstream program and efforts to improve the effectiveness of handling COVID-19, Kabupaten Jember has an excellent opportunity to make the upstream program more effective individually and culturally. The opportunity is related to the perspective of a person and a specific group in viewing reality.It should be noted that this research does not intend to focus on personal reality, but rather to 
understand how individuals and groups solve problems. This perspective is influenced by the culture around which they live. Therefore, this opportunity can be classified as culture-based handling of covid.

This opportunity uses the community's perspective on reality or what is known as a worldview and becomes one of the stepping stones for Jember Regency to optimize the culture that is developing there. Pendalungan is a distinct culture of Kabupaten Jember which has excellent potential to play an active role if it has functioned correctly. Moreover, since it was declared a Pendalungan city, it has consequences for the region's concern for cultural practices (Aziz, Setyobudi, \& Dwiatmini, 2021). This is an indication that Kabupaten Jember is not only concerned with the practice of Pendalungan culture but can also implement the culture in solving problems that occur in Kabupaten Jember.

Pendalungan was born from the acculturation of two dominant cultures, namely Java and Madura (Ayu $\mathrm{W}, 2018$ ) as the culture that became the identity of the Jember people who were fighters, aggressive, expansive, and had strong solidarity (Ekaraga, Widjajanti, \& Sulistyo, 2018). The specialty of Pendalungan also lies in the harmonization between cultures in the Pendalungan area which has a low rate of conflict compared to other regions in Indonesia (Satrio, 2019). Therefore, the uniqueness of the cultural character, namely gotong royong, which is owned by Jember, is considered to be its own potential in dealing with nonnatural disasters, COVID-19. Some other features are the hybridity pattern that will be explained in this study, which can illustrate that Jember has a different pattern from other regions, so that dynamics in handling COVID-19 require special care. This situation also requires exploring the perspective of the community towards a more objective reality.

No research explores the worldview of the Pendalungan culture. This research is expected to be the first step in extracting the worldview of the Pendalungan culture and can be a reference in efforts to handle COVID-19 in Kabupaten Jember. Tilburt (2010) states that worldview has a crucial role in overcoming health disparities within a community group (J. C. Tilburt, 2010). Analysis of the worldview can represent the orientation of a person or a group in understanding reality in several forms such as sociality, ethical, political, to spiritual aspects and how these aspects become one and coherent (Sheikh, 2021), so that awareness of worldview is one of them in handling Health care providers can avoid dangerous assumptions about patients that can be fatal to them (J. C. Tilburt, 2010). It can be said that understanding the worldview can help in handling disease outbreaks from education, prevention, treatment to post-treatment recovery for the community and health workers during the COVID-19 pandemic.

\section{Methods}

The research method used in this qualitative research is the descriptive method. The descriptive method is considered suitable as a tool to find the world view of the Pendalungan culture. The descriptive method is considered capable of explaining descriptively the facts contained in the Pendalungan culture systematically and objectively. The descriptive method is in line with the literature research used in this study.

The methodological element used in this research is the analytical method, according to Kaelan (2005). The steps applied are data reduction, data classification, data display, and carrying out interpretation and interpretation to get conclusions. First, the steps taken are to organize and summarize data related to the Pendalungan culture. The purpose of organizing is to make it easier to control data.

Second, the data that has been organized is classified according to the research objectives. The third is the power display used to adjust the classification results data with the formal object used. Finally, conclusions are obtained from the interpretation of the data that has been shown through previous efforts. Interpretation is carried out to go to the next stage, namely, interpretation to match the context of the data that has been owned. Conclusions are obtained through the inference process using a-posteriori logic (Kaelan, 2005:66-70).

\section{Pendalungan Culture}

Etymologically, Prawiroatmojo (1985) explains that Pendalungan comes from the word dhalung which means it is a big pot (Ekaraga et al., 2018). Saputri (2019) defines Pendalungan based on the Kamus Besar Bahasa Indonesia (KBBI), which uses Pandalungan as a large metal tray (Saputri, 2019). Raharjo (2006) in Satrio (2019) defines Pendalungan as a form of perception that arises as a result of the mixing between two 
major cultures, namely Madura and Java, which develops as a fact that both are the majority population that is growing, although in its development, it remains oriented towards Javanese culture (Satrio, 2019).

The Pendalungan culture occupies certain areas in East Java, precisely in the Horseshoe area which consists of several districts, namely Probolinggo, Pasuruan, Lumajang, Jember, Situbondo, Bondowoso, and some areas in Banyuwangi (Satrio, 2019). Regarding the geographical location, the mixing between the two tribes and several other ethnic groups who are immigrants created Pendalungan as a form of longing for their hometown. Pendalungan culture has a concept that does not yet have a clear meaning. However, most people try to define the culture as a mixture of the dominant cultures, namely Madura and Java (Saputri, 2019). Pendalungan is an imaginary reality made in the context of cultural politics as a form of life for several tribes and ethnicities that develop in an area (Zoebazary, 2017:51-52). Therefore, Pendalungan is also a requirement for legitimacy, identity, and recognition, which is still searching for a form (Ayu W, 2018).

The Pendalungan culture uses everyday language, namely the rough Javanese language or better known as ngoko and some mixtures with the language of Madura (Saputri, 2019). This language makes Javanese a language with a Jember dialect or a Javanese language that is different in structure from Javanese in general and can be interpreted that the dominance of Javanese culture is stronger than Madurese (Satrio, 2019). Aryani also explains that Pendalungan contains a lexical element which means saying and being civilized is not necessarily polite (Ayu W, 2018). This language or dialect of Pendalungan is often used as the outer shell to recognize the Pendalungan culture (Zoebazary, 2017:18).

\subsection{The History of Pendalungan in Jember}

According to Aryni Ayu W (2018), the history of Pendalungan in Kabupaten Jember. Pendalungan had a close relationship with the world when built during the Dutch colonial period in Kabupaten Jember. Before becoming a district, Jember was an afdelling part of Bondowoso and a sub-district in Puger District. Along with the rapid development of Jember, Jember has been used as a city since 1883.

The development of the City of Jember has a significant effect on social and cultural developments in Jember and the rapid economic growth that is happening. This also penetrated the main commodity in Jember, namely plantations controlled by the Dutch and opened up trade flows and increased transportation so that several ethnic groups such as Arabs and Chinese and Javanese and Madurese entered. In historical views, the Dutch workforce was carried by indigenous people from Solo, Madura, and surrounding cities (Ayu W, 2018).

In its development, regions that accept various ethnicities and ethnicities grow and create their own culture to strengthen the identity formed through the mixing of cultures found in these areas. Probolinggo and Jember regencies are some areas that use the Pendalungan culture as a cultural framework to sharpen their cultural identity.

Kabupaten Jember does not have a specific indigenous culture within its community. The developed culture is a hybrid culture resulting from a combination of Javanese and Madurese with close kinship relations (Koesoemawati, 2016). This definition was attached to Kabupaten Jember until, in 2016 it was designated as Pendalungan City (Aziz et al., 2021). Despite being a Pendalungan city, Pendalungan is still an imaginary discourse for Kabupaten Jember which can have the distribution of Pendalungan at a central point, not in the whole area as happened in Lumajang Regency (Satrio, 2019).

Satrio (2019) explained that the mixing or melting pot that occurred in Jember was in the middle of the city of Jember (Satrio, 2019). As a result, urban characters found in Kabupaten Jember such as business centers, offices, education are located in three golden triangle districts in Kabupaten Jember, namely Sumbersari, Kaliwates, and Patrang (Koesoemawati, 2016). However, the Pendalungan culture can also be found in several areas other than the middle of the city, namely some areas in the south and north. Cultural dominance between Java and Madura in an area can be a benchmark for the development of Pendalungan. This will also be explained more deeply in the hybridity pattern of the subsequent Pendalungan culture (Saputri, 2019).

In Figure 1, Yuswadi in Warsiman (2014) describes the meeting point between the two original cultures of the Pendalungan culture, namely Java and Madura. Their meeting took place in the middle. The middle area is the meeting place for the two, considering that the Javanese people who live in the south are looking for coastal life. Meanwhile, people with Madurese blood dominate the north, east, and west in line with the historical side of the colonial era which led them to occupy highland areas for gardening as workers on colonial lands. Therefore, the Pendalungan culture is often found in the Jember city area. The influence of the Pendalungan culture also gradually disappears as the radius of the area moves away from the city area (melting pot area) (Warsiman, 2014). 
Pendalungan is a culture created because of human nature in creating a culture that is characterized by its original life or like a hometown (Ayu W, 2018). These characteristics create the diversity of Pendalungan types that can be drawn according to the dominance of each region depending on the dominance of the tribes and ethnicities that inhabit the area.

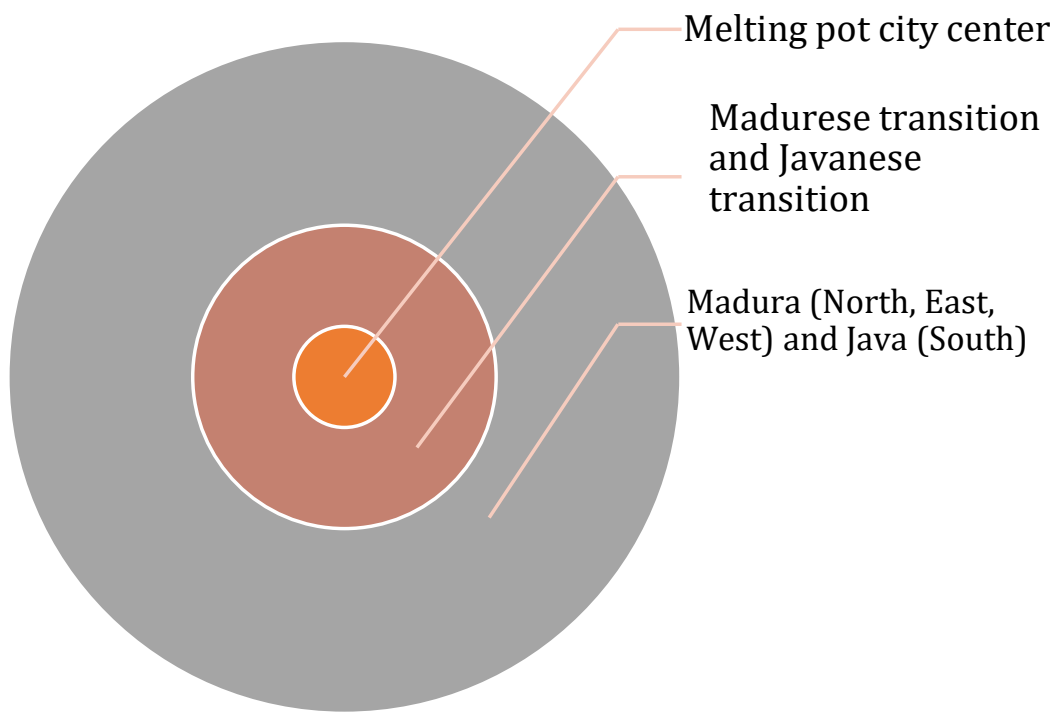

Fig. 1 Hibridity of Pendalungan culture Jember

\subsection{Worldview}

Worldviews are ways of thinking formed through social relationships and serve as instructions for a person or group to carry on life (Sartini, 2020:15). Tilburt (2007) defines a worldview as a philosophy of life to answer all fundamental questions about the existence of life (J. Tilburt \& Geller, 2007). From these two definitions, it can be concluded that a worldview is a tool used by humans to look at the reality that is formed based on its relationship with the surrounding environment. The worldview is like the glasses used by someone in understanding the reality they see. The glasses are formed from the relationship of the individual user with his environment which can be interpreted as the relationship between humans and nature (other than humans).

In contrast to the cultural capacity that is more about functioning effectively as a group or individual in the context of beliefs, behaviors, and needs presented to the community. Worldview understands cultural capacity, but worldview focuses on beliefs related to a particular culture (J. C. Tilburt, 2010). Therefore, Tilburt (2010) puts forward the linkage of beliefs to the role of worldview in a culture. These linkages are part of a culture that can unite beliefs, languages, and practices or actions.

\subsubsection{Categories of Worldview}

Sartini (2020) seeks to describe several categories of worldviews that are prerequisites for human relations with others and the surrounding environment:

1. Classification

Classification in the worldview is more about the distribution of general characteristics in different groups. This is also an understanding at the outset that the worldview is more of unification in a culture.

2. Time

The definition of time in the worldview relates to the view of a cultured community group in viewing the time for the implementation of the activities they do so that it is of relative value.

3. Space

Worldview in the spatial dimension of culture. The view of space is closely related to the existence of an object. Space is also related to directors or directions.

4. Relationship

The relationship between two or more people is described in the view of a culture.

5. Causality

The notion of causality is thick with the relationship between an event and its causal factors.

6. The self and the other 
The relationship between self and others is a self-definition influenced by the existence of the individual and his social environment. This is identical to individuals' formation through social relations, social construction, and attitudes towards them by these social conditions. However, it cannot be separated from the relationship between humans and non-humans. So, the other in question is other than the human self. What is outside of the self is something else.

\subsubsection{Worldview Function in Problem Solving}

Worldview for Sheikh (2021) has several things that can be useful from extracting worldviews from a culture. First, a worldview can describe different thoughts from ideology because they can reveal reality, not just rhetoric. Worldview analysis can reveal the truth behind other people's visions or other people's opinions. Second, worldview analysis can explain questions related to mobilization. This relates to why a worldview is adopted, maintained and disseminated in a relational context. Third, worldview analysis can also contribute to conflict analysis because it can monitor the way specific communities compete with each other and view learning from an existing problem (Sheikh, 2021)

Sartini and Ahimsa (2017) provide full support for developing research related to a worldview that will find the characteristics of each culture. Primarily if it is described through worldview categories, it will be more visible the characteristics of each culture (Sartini \& Ahimsa-Putra, 2017).

\subsection{The worldview of Pendalungan Culture}

Based on the explanation above, it can be concluded that the Pendalungan culture is a culture that has become a discourse and is still in the growth stage. However, it does not mean that the Pendalungan culture does not have a perspective or worldview that is used as glasses for the people of Jember in facing reality. The cultural worldview of Pendalungan is not fixed at the center of cultural development or one point. The worldview that will be discussed will be more comprehensive, namely an explanation that includes the Pendalungan culture at the central or urban point. This transition area includes the Java and Madura transitions and the culture found in the farthest radius from the main point. It can also be said that the analysis phase uses the hybridization pattern of Yuswadi (2006) in figure 1. The worldview that has been explored prioritizes the dynamism of the Pendalungan culture to explain the entire Pendalungan condition in Kabupaten Jember. This is supported by the statement by Satrio (2016) in Satrio (2019) that the cultural basis at the family level, which is required for hierarchical relationships and traditional values, depends on the dominance of the culture that surrounds the family (Satrio, 2019).

Therefore, looking back at the distribution and domination of ethnic and ethnic groups in the Kabupaten Jember is essential. Some of the weighting factors for making the Pendalungan culture stand alone are the existence, distribution, and discourse that are still thick in Kabupaten Jember. According to Hairunisya (2014), Pendalungan culture is rooted in entrepreneurship character education (Hairunisya, 2014). The history and present-day of the Pendalungan culture require that worldview excavation is not limited to the center point of hybridization but must also be linked to a wider radius as a unit of Pendalungan Kabupaten Jember.

The Worldview categorization study will be drawn from several forms of culture by Koentjaraningrat, namely ideas, habits, and artifacts (Yuliati, 2007). Worldview is a thought that can be expressed in various forms of the culture of the Pendalungan community. Therefore, in the following, we will discuss the worldview category contained in Pendalungan Jember in various forms of Pendalungan culture that developed in the city of Pendalungan, Jember. The worldview will be dominated by the worldview found in Pendalungan Jember arts, such as can macanan kadduk which according to Saputri (2019) is was an art that develops and is thick with elements of Pendalungan culture in Kabupaten Jember (Saputri, 2019).

1. Time

The concept of time owned by the Pendalungan community has many similarities with Javanese culture, which has vital elements of Islamic culture. It is also inevitable that the Madurese culture contained in the Pendalungan culture has a strong religious orientation. Moreover, the education of the Madurese in Jember is dominated by religious education such as pesantren. Therefore, the calendar and community activities depend on the Hijri calendar. The calendar is related to traditions closely related to Eid al-Fitr to the calculation of someone's death ceremony.

One of the Pendalungan traditions that are considered unique is the Kupatan tradition. The tradition is carried out on the eighth day of the month of Shawwal, which means it is the eighth day of the celebration of Eid al-Fitr. Kupatan in Kabupaten Jember is done in the prayer room or mosque. Local people make ketupat and lontong to be brought and collected to the place of worship as a symbol of admitting wrong and 
returning to holiness after fasting and carrying out holidays ("Tradisi Kupatan Budaya Pandalungan Kabupaten Jember," 2016).

However, the time system in Jember also depends on the calendar at harvest time. The Ta blindan tradition is one of the activities of the Jember community which depends on the time of harvest. Tabutaan is a tradition carried out in conjunction with the village dress ceremony which is routinely carried out at the time of the second harvest (Putri, Wanti, Jannah, Kurniasih, \& Nathassya, 2020)

2. Space

The concept of space for humans and non-humans (Sartini, 2020:190). The concept of human space with other humans is the concept of space that focuses on geographical concepts between humans and is usually equated with uniformity of dimensions or space or occupying the same dimensions and space. However, this is different in the space between humans and non-humans, which is more often referred to as the spirit or in other dimensions.

The concept of inter-human bareness in the Pendalungan culture is found in the division and rooted in the understanding that the Madurese inhabit the northern part of Jember and the eastern part and the western part and the Javanese occupy the southern part of an area that is identical to the coast. This uncertainty finally made a point of acculturation explained at the meeting point between the two. From this definition, it can be said that there is a reasonably strong line to distinguish the two of them. Of course, this is different from the state of the distribution of the Pendalungan culture in Lumajang Regency which tends to be comprehensive. Both Javanese and Madurese cultures are more flexible in their attachment to space (Satrio, 2019).

The concept of space between humans and non-humans can be illustrated from the ritual of summoning spirits when the macanan kadduk art begins (Suryandari, 2017). The ritual of summoning spirits can be interpreted as an attempt to invite because it does not occupy the same space as the person who invites. Therefore, it can be concluded that the view of the Pendalungan community is the separation of places between humans and non-humans.

\section{Self \& Others}

In this worldview, the self and others are more about the perception or awareness of the self and other things that exist outside the self. The people of Jember understand that self is what is the history of themselves personally which is formed from where the tribe and origin were before settling in Jember. The self of the Pendalungan community is a description of the self-identity of acculturation products.

The Pendalungan community's view of other people in Jember is that of fellow immigrants in Jember. The strategy is explained by Berry (2006) in Satrio (2019) that in the Pendalungan culture, each individual still maintains their original culture but still wants to contribute to the new culture that comes. Therefore, the inter-ethnic conflict involving Madura in that occurred in the Pendalungan area can be categorized as low compared to other regions in Indonesia (Satrio, 2019).

4. Causality

The causal relationship in the Pendalungan culture can be seen from the art of can macanan kadduk and tabutaan as well, where the purpose of holding the art of can macanan kadduk is to ward off harm in the agricultural land of the Jember people (Saputri, 2019). The purpose of can macanan kadduk has similarities with tabutaan which makes the tabutaan tradition held until now to ward off the harm that can take happiness from society if it is not removed (Farizi, 2017).

One thing that needs to be underlined regarding the causal relationship above is that historicity is a valuable thing for the people of Jember. It is not only used as a lesson for life in the present and the future, but also relates to inheritance to the next generation in the form of art and other forms of culture. In tabutaan art, the people of Desa Kamal where the art is preserved highly uphold the family lineage and emphasize ancestral messages in every ritual performed (Putri et al., 2020). Therefore, events that occurred in the past are used as learning which is also manifested by self and cultural identity.

The causality in the two arts can be drawn straight with several other worldview categories. Sartini (2020) states that the causality category cannot be separated from several other categories.

5. Relationship

Afif (2015) in Satrio (2019) relates to social comparisons, this occurs when there is a negative and positive evaluation of each other. The main factor is the history that makes the Javanese kingdom the ruler of the Madurese community. This control has an effect until now, although the ties of brotherhood that have existed are no longer strongly bound to the Madurese community in their original area. The negative evaluation of the Madurese by the Javanese and vice versa, still affects the culture that occurs in Pendalungan (Satrio, 2019).

6. Classification 
Classification is placed in the last explanation because it is considered the key to the worldview of the Pendalungan culture lies in the category of worldview classification. Pendalungan still cannot be classified as a new culture or totally different from the ethnic and ethnic groups that develop within it. However, this is what makes the Pendalungan worldview classification point.

The Pendalungan culture is still trying to build their own identity. The development of art and new cultural forms have begun to be made. Therefore, the Pendalungan culture tries to illustrate that Pendalungan is a real situation by trying to distinguish the non-Pendalungan culture from the Pendalungan culture which needs to be explored and developed. The classification does not only lie in self-identity over ethnicity, ethnicity, or area of origin, but also has an attempt to redefine, reclassify the Pendalungan itself. The Pendalungan community tries to interpret their existence and relationship by not leaving their identity as immigrants through Pendalungan. Pendalungan is a symbol of the presence and togetherness of the local community.

\subsection{The function of the Worldview of Pendalungan Culture is to deal with (preventive, treatment, and recovery) pandemics/disasters}

The government has regulated health efforts in UU No. 36 of 2009 which is stated in article 1 that health efforts are a series of activities carried out in an integrated manner to improve public health status in the form of disease prevention, health improvement, disease treatment, and health restoration by the government and or society. These efforts are described in the following paragraphs regarding promotive health services as a series of health services that prioritize health promotion. Prevention is an activity to prevent health problems or diseases. Curative service means a series of activities for treatment aimed at healing disease, reducing suffering due to disease, controlling disease or disability so that the quality of sufferers can be maintained as well as possible. Finally, rehabilitation is a series of health services that aim to return former sufferers to society.

The series of health efforts requires an understanding from health workers on the things that must be underlined to prevent and recover from disease and requires an approach that can bring health workers closer to the community or patients. Tiburt (2010) states that appreciating or appreciating the patient's worldview can provide mental closeness with health workers. Of course, it is also possible to approach in terms of promotion and prevention because of the closeness of mentality and a sense of comfort that has been obtained. Therefore, health workers must learn about the complexities of knowledge related to the worldview in order to be able to effectively communicate with patients and even certain population groups who are reluctant to provide explanations regarding their worldview (J. C. Tilburt, 2010). This is done to be able to consider the medical treatment provided.

The worldview of Pendalungan culture can be applied as part of the efforts of the government and health workers in Kabupaten Jember in carrying out health efforts in dealing with COVID-19. Starting from promotive to rehabilitative treatment, which making worldview as an approach to these efforts. Health efforts are a series of activities that are carried out continuously. Therefore, the worldview of Pendalungan can be used in the promotion to the rehabilitation process.

Aside from being a medium for approaching patients and the community, worldview Pendalungan can be used as a practice for health workers to provide more optimal services. Tilburt (2010) provides the view that understanding or awareness of the worldview can provide health workers with an understanding of diversity and reflection on their limitations in knowledge so that they can understand the diversity that occurs in society (J. C. Tilburt, 2010). 


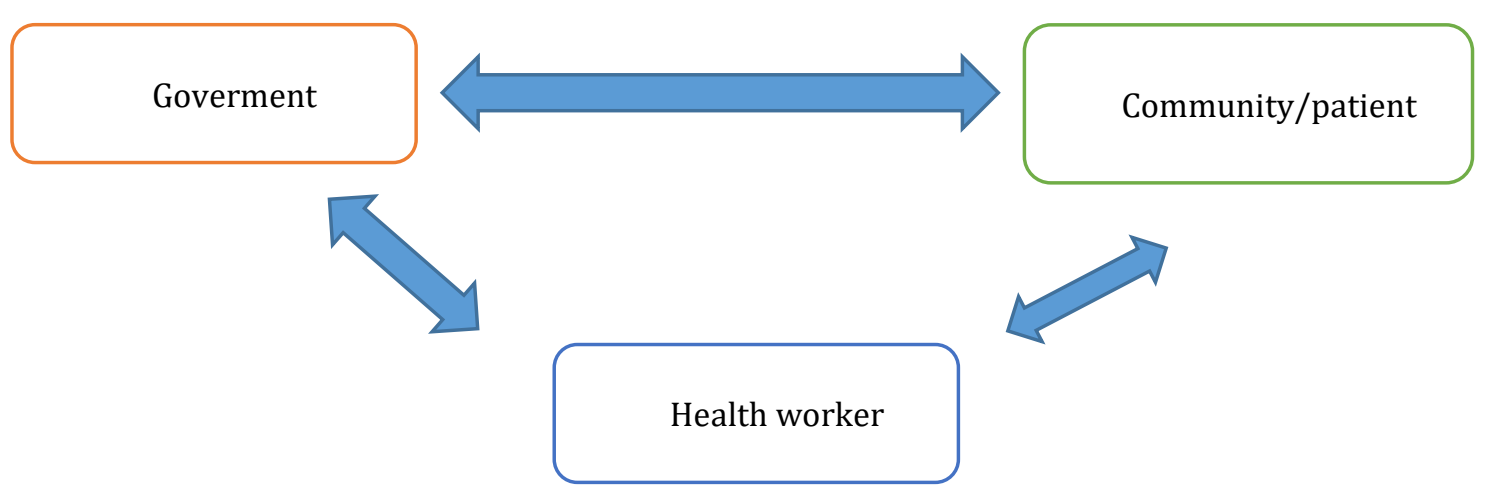

Fig. 2 Worldview understanding schema

Figure 2 describes the scheme of the flow of worldview understanding that can be carried out by the government, health workers, and the community in improving health services. The scheme shows the close relationship between the three and does not escape the worldview function in the world of health that has been described previously. The scheme is to make it easier to understand the flow and role of Worldview in dealing with the COVID-19 pandemic.

The main step for the government to understand community's worldview based on cultural domination which is carried out actively or reciprocally. It aims to provide health promotion that is right on target with the right meaning in understanding the worldview of the community so that it uses events that are more effective in seeking disease prevention and improving public health status. The government also seeks to provide education to health workers on the cultural knowledge (worldview) of the community based on the dominance of the culture in which the community or patient lives. These efforts aim to make it easier for health workers to identify the culture of the community and patients in providing health promotion and early treatment so that treatment is maximized. Health workers can also communicate with the government regarding cultural control in terms of health for policy considerations to be taken. The relationship between patients and health workers needed is an understanding of the patient's worldview so that treatment and healing is faster.

\section{Conclusion}

The worldview of the Pendalungan culture has several categories that explain the Pendalungan community's view of the world which includes time, space, themselves, other humans and things that are outside of themselves and the environment. These views can be observed and understood in health efforts, which consist of several series of treatments, starting from promotion, prevention, curative to rehabilitative.

Worldview Pendalungan in health promotion efforts can be used in an approach to the community by ensuring that health promotion is carried out by procedures and taking into account the views of the Pendalungan community in understanding fellow humans so that health workers and the government can place themselves. Health workers and the government can also understand that some cultures are still tied individually to the ethnicity or origin of the local community. One example is when conducting health promotion in the northern area of Jember, the approach uses the Madurese language or treats the community as one's own family considering the close kinship of the Madurese community.

This method can also be done during preventive to rehabilitative implementation. Understanding the worldview in patients is expected to help workers understand patients and reduce negative assessments of them. In addition to preventing treatment that is not considered suitable for non-compliance with norms, a worldview can also help increase hope for recovery and enthusiasm for patients and maintain health. Therefore, the world view of the Pendalungan community can be one of the efforts to deal with the Covid19 pandemic in the Kabupaten Jember. 


\section{References}

Ayu W, A. (2018). Nama Diri Pendalungan Jember dalam Kebermaknaan Sosial Budaya. Jantra Jurnal Sejarah Dan Budaya, 13(1), 25-42.

Aziz, F. F., Setyobudi, I., \& Dwiatmini, S. (2021). Imajinasi Identitas Orang Jember: Wacana Pendalungan Beserta Efeknya. Budaya Etnika, 5(1).

Diskominfo.jemberkab.go.id. (2021). Pemkab Jember Optimalkan Penanganan Sistem Hulu untuk Cegah Penyebaran Covi-d19. Retrieved from Diskominfo Kabupaten Jember website: https://diskominfo.jemberkab.go.id/blog/detail/Pemkab-Jember-Optimalkan-Penanganan-SistemHulu-untuk-Cegah-Penyebaran-Covid-19

Ekaraga, A. W., Widjajanti, W. W., \& Sulistyo, B. W. (2018). The Applications of Traditional Javanese Architecture with Javanese Philosophy for East Java Cultural Attractions Complex in Surabaya. IPTEK Journal of Proceeding Series, (6), 1-5.

Farizi, A. (2017). Penerapan Strategi Pemasaran Industri Kreatif Batik Jember dalam Upaya Meningkatkan Daya Saing (Studi pada Rumah Batik Rolla Kabupaten Jember). Jurnal Ilmiah Mahasiswa FEB فnرهن نوين\&option=com_dbook\&task=readonline\&book_id=13650\&page=73\&chkhashk=ED9C9491B4\&Ite mid=218\&lang=fa\&tmpl=component

Hairunisya, N. (2014). Pendalungan Culture as The Root of Character Education Entrepreneurship. Journal of Asian Scientific Reseach, 4(11), 677-689.

Kaelan. (2005). Metode Penelitian Kualitatif Bidang Filsafat (I; K.- Riyanto, Ed.). Yogyakarta: Paradigma.

Koesoemawati, D. J. (2016). Social Cohesion of Pendalungan Community and Urban. Komunitas: International Journal of Indonesian Society and Culture, 8(37), 145-154. https://doi.org/http://dx.doi.org/10.15294/komunitas.v8i1.4872

Putri, D. R., Wanti, R. S., Jannah, F. R., Kurniasih, A., \& Nathassya, A. B. (2020). Eksistensi Kesenian Ta ' Buthaan Serta Relasi Kuasa. Jurnal Ilmiah Dinamika Sosial, 4(1), 24-42. Retrieved from Journal.undiknas.ac.id

Saputri, L. (2019). Pengaruh Budaya Pandalungan pada Bentuk Penyajian Kesenian Can Macanan Kadduk. Invensi, 4(2), 167-183.

Sartini. (2020). Wisdom from Rural Java (1st ed.; Novie, Ed.). Yogyakarta: Gadjah Mada University Press.

Sartini, S., \& Ahimsa-Putra, H. S. (2017). Preliminary Study on Worldviews. Jurnal Humaniora, 29(3), 265. https://doi.org/10.22146/jh.29690

Satrio, P. (2019). Transmisi Budaya dan Identitas Sosial pada Masyarakat Pendalungan. Prosiding Seminar Nasional \& Call Paper Psikologi 2019: Psikologi Sosial Di Era Revolusi Industri 4.0 Peluang Dan Tantangan Fakultas Pendidikan PSikologi 4 Mei 2019, 235-241.

Saubani, A. (2021). Bupati Jember akan Lanjutkan PPKM Mikro di Tingkat RT/RW. Republika.Co.Id. Retrieved from https://republika.co.id/berita/qxkw60409/bupati-jember-akan-lanjutkan-ppkmmikro-di-tingkat-rtrw

Sheikh, M. K. (2021). Worldviews: Competing Perceptions of The World. Retrieved from https://www.jstor.org/stable/resrep31655.15

Suryandari, N. (2017). EKSISTENSI IDENTITAS KULTURAL DI TENGAH MASYARAKAT MULTIKULTUR DAN DESAKAN BUDAYA GLOBAL. Jurnal Komunikasi, 11(1), 21. https://doi.org/10.21107/ilkom.v11i1.2832 
Tilburt, J. C. (2010). The Role of Worldviews in Health Disparities Education. Journal of General Internal Medicine, 25(S2), 178-181. https://doi.org/10.1007/s11606-009-1229-9

Tilburt, J., \& Geller, G. (2007). Viewpoint : The Importance of Worldviews for Medical Education. Academic Medicine, 82(8), 819-822.

Tradisi Kupatan Budaya Pandalungan Kabupaten Jember. (2016). Retrieved from pasca.unej.ac.id website: http://pasca.unej.ac.id/tradisi-kupatan-budaya-pandalungan-kabupaten-jember/

Warsiman. (2014). Penguatan Identitas Budaya Lokal Jawa Timur. Malang: Universitas Brawijaya Press.

Yuliati, D. (2007). Kebudayaan Lokal Vs Kebudayaan Global: Hidup atau Mati? Jurnal Sejarah : Citra Lekha, pp. $1-10$.

Zoebazary, M. I. (2017). Orang Pendalungan Penganyam Kebudayaan di Tapal Kuda (II). jember: Paguyuban Pandhalungan Jember. 